\title{
Pemodelan Data Kelahiran Anak Pertama Menggunakan Regresi Cox Proportional Hazard
}

\author{
Mahfuz Hudori*1, Erfiani ${ }^{2}$, Muhammad Nur Aidi ${ }^{3}$ \\ ${ }^{1}$ Dosen Program Studi Teknik Sipil Universitas Internasional Batam \\ ${ }^{2,3}$ Institut Pertanian Bogor \\ e-mail: ${ }^{* 1}$ mahfuz@uib.ac.id, ${ }^{2}$ erfiani_ipb@yahoo.com, ${ }^{3}$ nuraidi@yahoo.com
}

\begin{abstract}
Abstrak
Setiap pasangan yang baru menikah memiliki waktu tunggu yang berbeda-beda untuk mendapatkan anak pertama. Perbedan waktu tunggu tersebut dapat disebabkan oleh adanya faktor internal atau eksternal dari pasangan yang baru menikah. Waktu yang dibutuhkan oleh setiap pasangan yang baru menikah sampai mendapatkan anak pertama merupakan bentuk dari survival time. Menganalisis hubungan antara survival time dan variabel bebas dapat dilakukan menggunakan model regresi cox proportional hazard. Berdasarkan penelitian yang dilakukan, variabel bebas yang memberikan pengaruh nyata $(\alpha=5 \%)$ terhadap waktu tunggu sampai mendapatkan anak pertama bagi pasangan yang baru menikah di Provinsi Lampung adalah variabel tempat tinggal, tingkat pendidikan, pengetahuan tentang kesehatan kehamilan dan usia pada saat menikah.
\end{abstract}

Kata kunci : Anak pertama, Cox proportional hazard, Regresi, Survival anlysis.

\section{PENDAHULUAN}

Jumlah penduduk provinsi Lampung pada tahun 2010 berjumlah 7,6 juta jiwa dengan pertumbuhan penduduknya mencapai $1,24 \%$ per tahunnya (Sensus Penduduk 2010). Hasil proyeksi jumlah penduduk pada tahun 2018-2020 menempatkan Provinsi Lampung sebagai provinsi terbesar kedua di pulau Sumatra dengan jumlah penduduk mencapai 8,5 juta jiwa (Badan Pusat Statistik, 2015). Cepatnya laju pertumbuhan penduduk Provinsi Lampung ditentukan oleh banyaknya angka kelahiran dan kematian serta data penduduk yang berpindah domisili. Dari ketiga faktor tersebut, peningkatan angka kelahiran di Provinsi Lampung sebagai faktor yang sangat signifikan dalam menaikkan pertumbuhan penduduk. Meningkatnya angka kelahiran di Provinsi Lampung sangat erat kaitannya dengan keberadaan pasangan yang baru menikah. Dari pasangan yang baru menikah tersebut akan lahir individu-individu baru yang akan mengisi daftar penduduk baru di Provinsi Lampung. Akan tetapi, setiap pasangan yang baru menikah tersebut memiliki selang waktu yang berbeda-beda untuk memperoleh keturunan pertamanya, yaitu ada yang cepat dikaruniai anak pertama dan ada juga yang harus menunggu dalam selang waktu yang lama. Selang waktu yang berbeda-beda dalam menanti kehadiran anak pertama bagi pasangan baru dapat disebabkan oleh faktor internal dan internal dari pasangan baru tersebut.

Pengindentifikasian faktor-faktor yang diduga berpengaruh terhadap waktu tunggu mendapatkan anak pertama bagi pasangan yang baru menikah dapat dilakukan dengan menggunakan pendekatan statistika. Selang waktu yang dibutuhkan oleh setiap pasangan yang baru menikah sampai dikaruniai anak pertama merupakan salah satu contoh survival time. Untuk menganalisis hubungan antara survival time dan variabel bebas dapat dilakukan menggunakan model regresi cox proportional hazard. Pemilihan model regresi cox proportional hazard dikarenakan ia mampu menangani data yang bersifat tersensor dan cukup handal (robust) (Kleinbaum \& Klein, 2011). Kehandalannya juga membuat model regresi cox proportional hazard banyak digunakan dalam penelitian di bidang pendidikan (Faruk et al., 2014) dan kesehatan (Al Farisyi \& Khambri, 2018; Setiani et al., 2019). 


\section{METODE PENELITIAN}

\subsection{Data Penelitian}

Data penelitian yang digunakan merupakan hasil Survei Demografi dan Kesehatan Indonesia (SDKI) tahun 2012 untuk Provinsi Lampung. Dalam penelitian ini pengamatan dibatasi hanya pada kelompok wanita dari pasangan baru yang sudah menikah dengan selang waktu amatan dari tahun pertama pernikahan sampai dengan tahun 2012. Variabel respon penelitian didefinisikan sebagai waktu tunggu mendapatkan anak pertama di Provinsi Lampung dan variabel bebas yang digunakan dapat dilihat pada Tabel 1 berikut:

Tabel 1. Variabel bebas penelitian

\begin{tabular}{|c|l|l|}
\hline Nama Variabel & Keterangan & Koding \\
\hline $\mathrm{X}_{1}$ & Tempat tinggal & $\begin{array}{l}0=\text { Kota } \\
1=\text { Desa }\end{array}$ \\
\hline \multirow{2}{*}{$\mathrm{X}_{2}$} & Tingkat pendidikan & $\begin{array}{l}0=\text { Lulus SD } \\
1=\text { Lulus SMP } \\
2=\text { Lulus SMA atau lebih }\end{array}$ \\
\hline \multirow{2}{*}{$\mathrm{X}_{3}$} & Status pekerjaan & $\begin{array}{l}0=\text { Tidak Bekerja } \\
1=\text { Bekerja }\end{array}$ \\
\hline \multirow{2}{*}{$\mathrm{X}_{4}$} & Pengetahuan tentang & $\begin{array}{l}0=\text { Tidak mengetahui } \\
1=\text { Mengetahui }\end{array}$ \\
\hline \multirow{2}{*}{$\mathrm{X}_{5}$} & kesehatan kehamilan & $\begin{array}{l}0=15-20 \text { tahun } \\
1=21-25 \text { tahun } \\
2=\text { untuk yang }>25 \text { tahun }\end{array}$ \\
\hline
\end{tabular}

\subsection{Metode Analisis Data}

Prosedur penelitian yang dilakukan dalam penelitian ini adalah sebagai berikut :

(i) Melakukan pemodelan regresi cox proportional hazard dengan formula :

$$
h(t)=h_{0}(t) \exp \left(\sum_{k=1}^{p} \beta_{k} X_{k}\right)
$$

dengan :

$t \quad=$ waktu melahirkan anak pertama

$h(t)=$ resiko wanita yang telah menikah untuk pertama kali dalam menunggu kelahiran anak pertama pada waktu $t$

$h_{0}(t)=$ baseline hazard function

$\beta_{k}=\left(\beta_{1}, \beta_{2}, \ldots, \beta_{p}\right)$ adalah koefisien regresi

$\boldsymbol{X}=$ variabel bebas.

(ii) Menentukan variabel bebas yang memberikan pengaruh terhadap waktu tunggu mendapatkan anak pertama dengan menggunakan likelihood ratio test dan wald test (Hudori, 2016).

(iii) Melakukan pengujian pemenuhan asumsi proportional hazard untuk setiap varaibel bebas menggunakan pendekatan grafik plot minus log survival (Marisa et al., 2017).

(iv) Melakukan pemilihan model terbaik menggunakan seleksi forward dan menginterpretasikan hasil luaran dari model terpilih. 


\section{HASIL DAN PEMBAHASAN}

\subsection{Deskripsi Data}

Responden perempuan pada penelitian ini berjumlah 2501 dengan $64.29 \%$ bertempat tinggal di desa dan $35.71 \%$ tinggal di kota. Dengan perbedaan tempat tinggal yang cukup besar rentangnya, sebagian besar perempuan telah menikah saat berusia 15-21 tahun (76.21\%), 21-25 tahun (20.27\%) dan > 25 tahun (3.52\%). Keberagaman usia pernikahan yang terjadi didominasi oleh perempuan dengan tingkat pendidikan SD (53.18\%), SMP (41.42\%), dan SMA atau SMA atau jenjang yang lebih tinggi (4\%). Di sisi lain, 66.09\% perempuan yang telah menikah di Provinsi Lampung juga berperan sebagai pekerja dan $33.91 \%$ lainnya memilih tidak bekerja (ibu rumah tangga). Kondisi perekonomian yang tidak merata tersebut diikuti dengan kurangnya pengetahuan responden tentang kesehatan seputar kehamilan. Di antara mereka hanya sebesar $51.66 \%$ yang telah memahami kesehatan seputar kehamilan, sedangkan $48.34 \%$ belum mamahami pengetahuan tersebut.

Rata-rata waktu tunggu mendapatkan anak pertama bagi perempuan yang bertempat tinggal di desa adalah 17.13 bulan dan 22.66 bulan untuk perempuan yang bertempat tinggal di kota. Jika dilihat dari tingkat pendidikannya, perempuan dengan tingkat pendidikan lulus SD memiliki rata-rata waktu tunggu mendapatkan anak pertamanya selama 14.54 bulan. Waktu tunggu tersebut lebih pendek dibandingkan perempuan yang lulus SMP (20.26 bulan) atau lulus SMA (39.20 bulan). Usia awal pernikahan juga memberikan perbedaan, ratarata waktu tunggu mendapatkan anak pertama bagi perempuan yang menikah di usia 15-20 tahun, usia 21-25 tahun dan usia >25 tahun masing-masing adalah selama 11.99 bulan, 26.99 bulan dan 89.31 bulan. Pengetahuan kesehatan seputar kehamilan seharusnya dimiliki oleh setiap pasangan yang baru menikah agar dapat merencanakan kehamilan sesuai dengan program kehamilan yang direncanakan. Perempuan yang mendapatkan pengetahuan tentang kesehatan kehamilan memiliki rata-rata waktu tunggu mendapatkan anak pertamanya selama 20.45 bulan, sedangkan perempuan yang tidak mendapatkan pengetahuan tentang kesehatan kehamilan memiliki rata-rata waktu tunggu mendapatkan anak pertamanya selama 17.45 bulan.

\subsection{Uji asumsi proportional hazard}

Pengujian pemenuhan asumsi proportional hazard dilakukan terhadap masing-masing variabel bebas menggunakan pendekatan grafik plot log minus log survival dengan luaran hasil pengujiannya sebagai berikut:

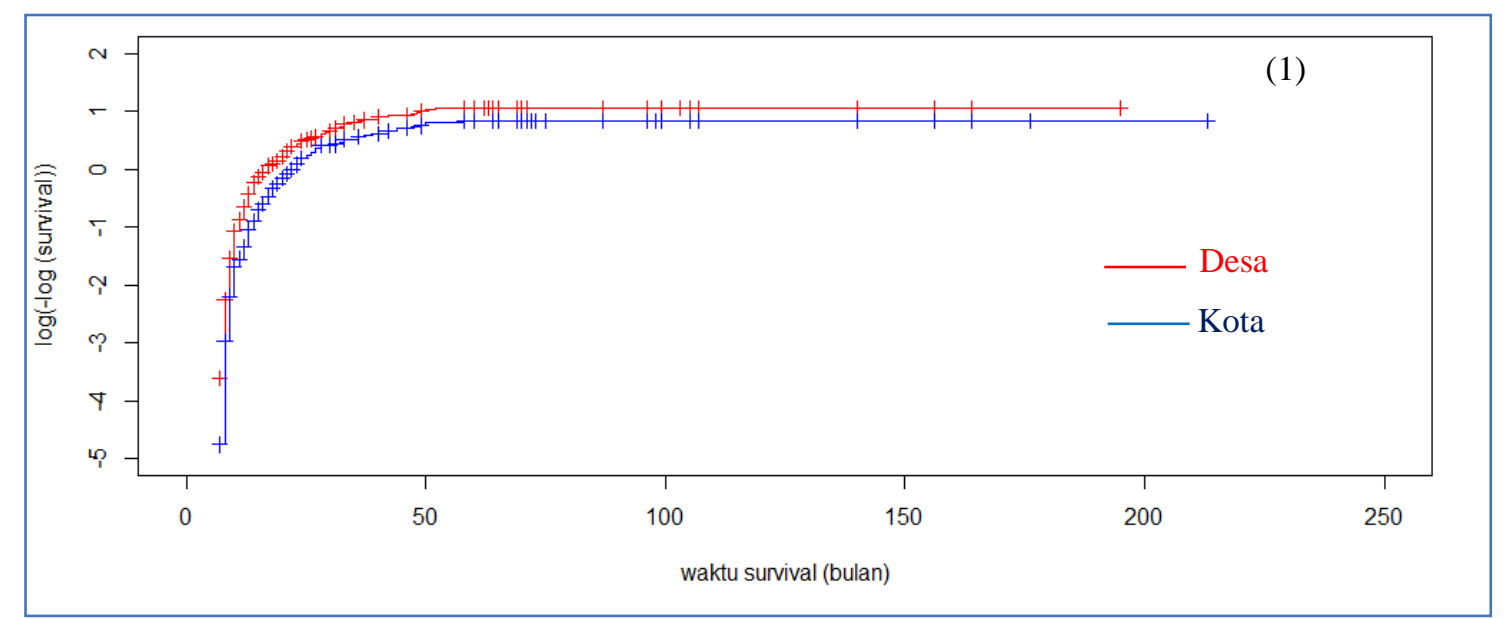

Gambar 1. Grafik log minus log survival variabel $\mathrm{X}_{1}$ (tempat tinggal) 
https://jurnal.unsulbar.ac.id/index.php/saintifik

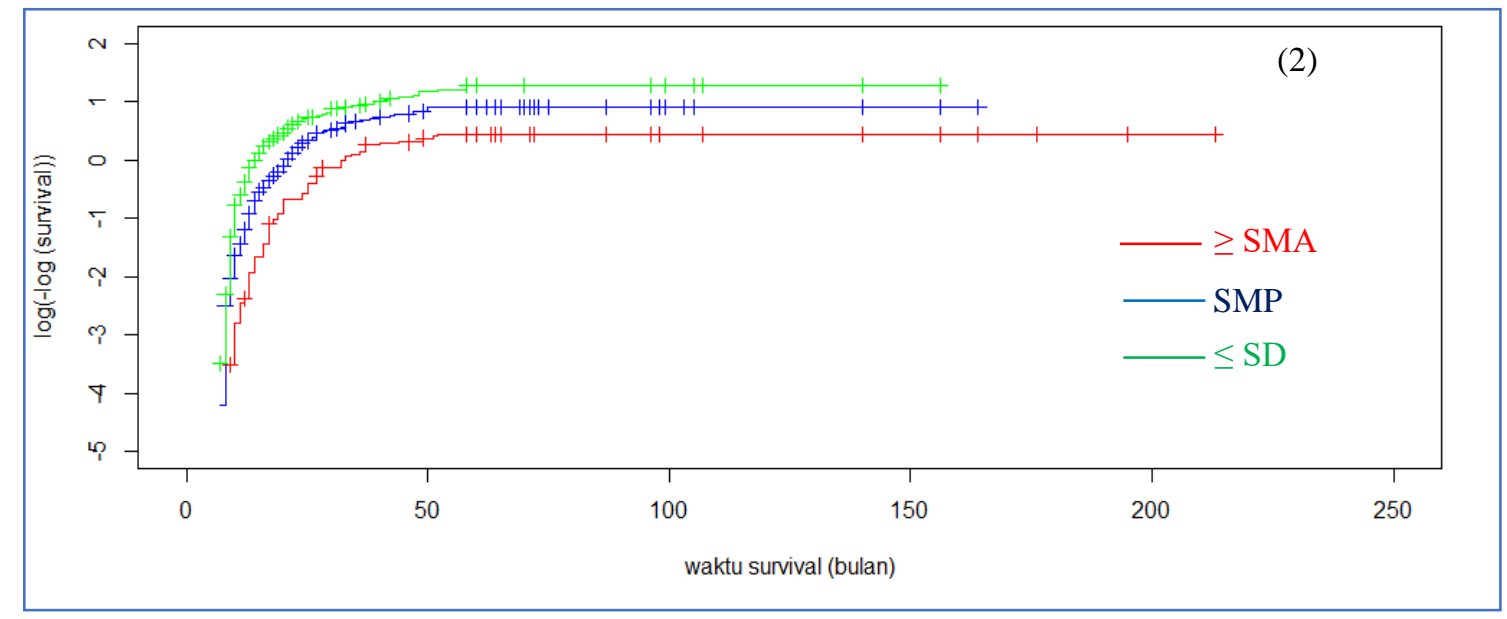

Gambar 2. Grafik log minus log survival variabel $\mathrm{X}_{2}$ (tingkat pendidikan)

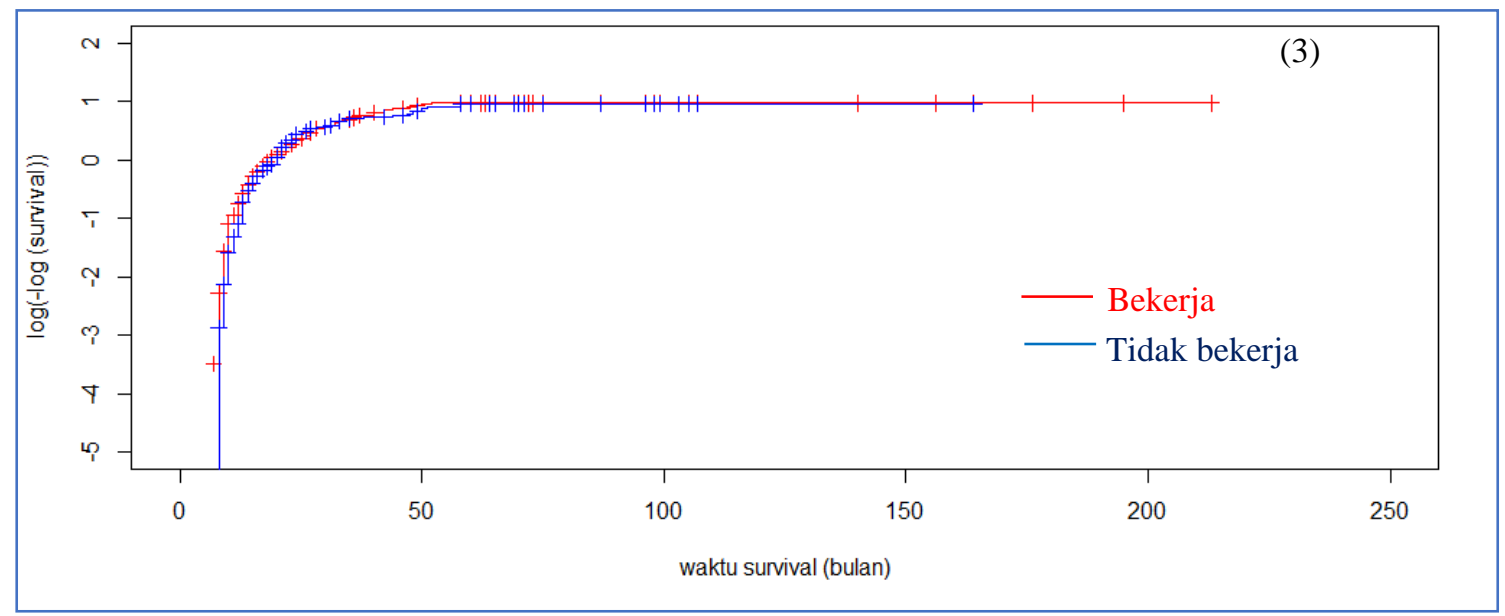

Gambar 3. Grafik log minus log survival variabel $\mathrm{X}_{3}$ (status pekerjaan)

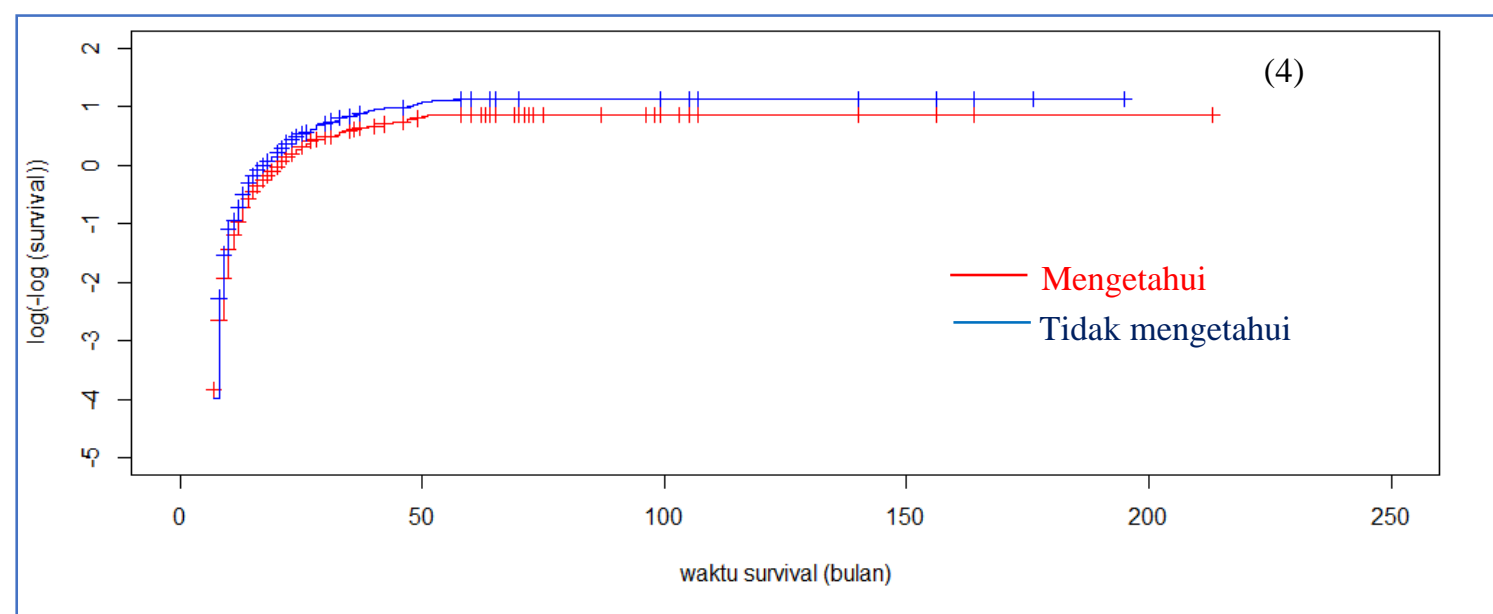

Gambar 4. Grafik log minus log survival variabel $\mathrm{X}_{4}$ (pengetahuan tentang kesehatan kehamilan) 
https://jurnal.unsulbar.ac.id/index.php/saintifik

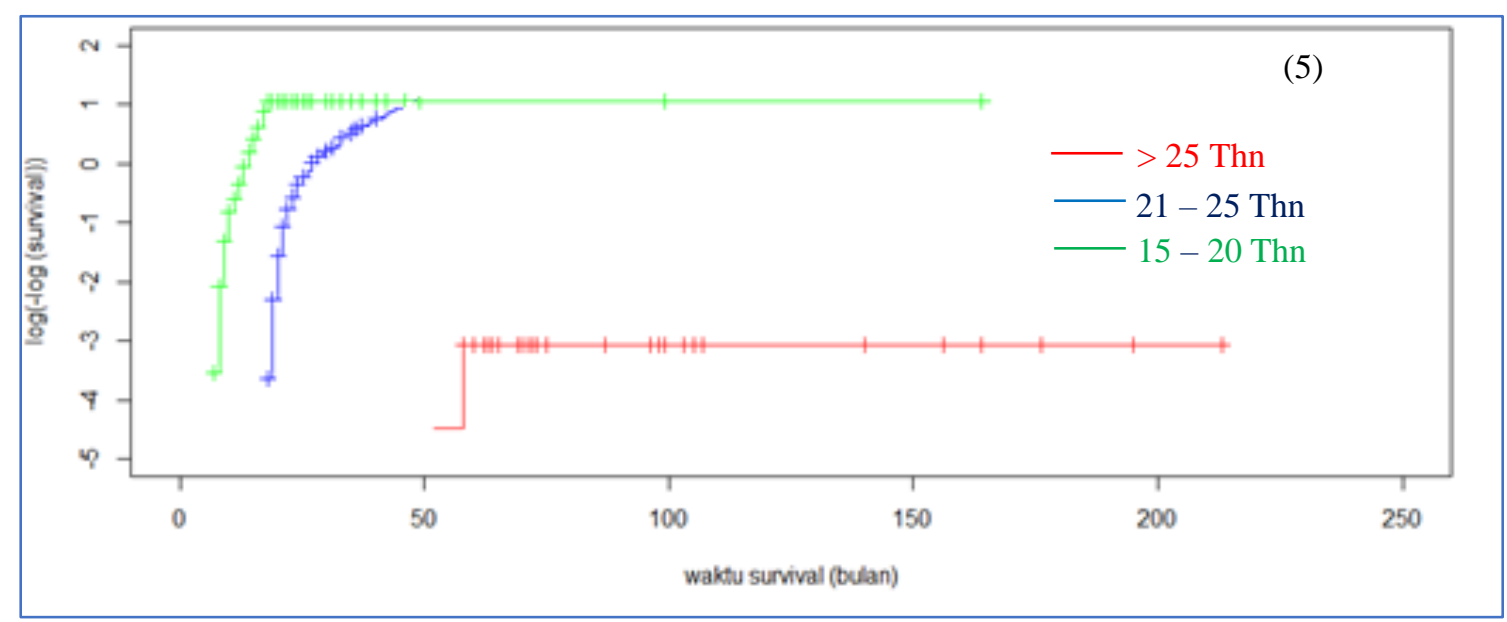

Gambar 5. Grafik log minus log survival variabel $\mathrm{X}_{5}$ (usia pada saat menikah)

Grafik plot log minus log survival (Gambar 1-5) menunjukkan bahwa plot grafik pada variabel $\mathrm{X}_{3}$ (status pekerjaan) saling berpotongan. Plot garis yang saling berpotongan dalam grafik plot log minus log survival memberikan petunjuk terjadinya pelanggaran asumsi proportional hazard, sehingga variabel $\mathrm{X}_{3}$ (status pekerjaan) dinyatakan tidak memenuhi asumsi proportional hazard. Sedangkan grafik plot log minus log survival untuk masing-masing variabel $\mathrm{X}_{1}$ (tempat tinggal), $\mathrm{X}_{2}$ (tingkat pendidikan), $\mathrm{X}_{4}$ (pengetahuan tentang kesehatan kehamilan) dan $\mathrm{X}_{5}$ (usia pada saat menikah) menunjukkan plot garis yang tidak saling berpotongan dan terlihat hampir sejajar antara plot garis yang satu dengan yang lainnya, sehingga dapat dinyatakan bahwa variabel-variabel tersebut memenuhi asumsi proportional hazard.

\subsection{Model Regresi Cox Proportional Hazard}

Variabel bebas yang digunakan pada model regresi cox proportional hazard merupakan variabel bebas yang berpengaruh nyata (signifikan) dan memenuhi asumsi proportional hazard. Hasil analisis pemodelan menggunakan variabel bebas yang memenuhi kriteria tersebut dapat dilihat melalui Tabel 3 berikut:

Tabel 2. Luaran koefisien regresi cox proportional hazard

\begin{tabular}{|c|c|c|c|c|c|c|}
\hline Variabel & Koefisien & Standard Error & Wald & df & p-value & Rasio Hazard \\
\hline $\mathrm{X}_{1}$ & 0.123 & 0.055 & 4.966 & 1 & 0.026 & 1.131 \\
\hline $\mathrm{X}_{2}$ & & & 25.461 & 2 & 0.000 & \\
\hline $\mathrm{X}_{2(1)}$ & -0.299 & 0.112 & 7.123 & 1 & 0.008 & 0.742 \\
\hline $\mathrm{X}_{2(2)}$ & -0.267 & 0.054 & 24.028 & 1 & 0.000 & 0.766 \\
\hline $\mathrm{X}_{4}$ & -0.095 & 0.053 & 3.181 & 1 & 0.075 & 0.909 \\
\hline $\mathrm{X}_{5}$ & & & 679.402 & 2 & 0.000 & \\
\hline $\mathrm{X}_{5(1)}$ & -5.823 & 0.509 & 130.934 & 1 & 0.000 & 0.003 \\
\hline $\mathrm{X}_{5(2)}$ & -1.665 & 0.069 & 584.645 & 1 & 0.000 & 0.189 \\
\hline
\end{tabular}

Hasil perhitungan dan analisis pada Tabel 2 menghasilkan nilai -2 Log Likelihood = 19278.57 dengan $p$-value $=0,00$. Perolehan nilai $p$-value $=0,00$ yang lebih kecil dari taraf nyata $\alpha=5 \%$ memberikan sebuah kesimpulan bahwa model penelitian memiliki minimal satu variabel bebas yang memberikan pengaruh nyata terhadap waktu tunggu mendapatkan anak pertama. Hasil wald test dengan taraf nyata $\alpha=5 \%$ (Tabel 2) juga semakin memperjelas kontribusi variabel bebas yang memberikan pengaruh nyata terhadap waktu tunggu mendapatkan anak pertama. Variabel bebas yang berpengaruh nyata tersebut yaitu: $\mathrm{X}_{1}$ (tempat tinggal), $\mathrm{X}_{2}$ (tingkat pendidikan), $\mathrm{X}_{4}$ (pengetahuan tentang kesehatan kehamilan) dan $\mathrm{X}_{5}$ (usia pada saat menikah). Sehingga model persamaan regresi cox proportional hazard yang terbentuk adalah sebagai berikut: 
https://jurnal.unsulbar.ac.id/index.php/saintifik

$\mathrm{h}(\mathrm{t})=\mathrm{h}_{0}(\mathrm{t}) \exp \left[0.123 \mathrm{X}_{1}-0.299 \mathrm{X}_{2(1)}-0.267 \mathrm{X}_{2(2)}-0.095 \mathrm{X}_{4}-5.823 \mathrm{X}_{5(1)}-1.665 \mathrm{X}_{5(2)}\right]$

Berdasarkan model persamaan regresi cox proportional hazard dan luaran pada Tabel 2, diketahui bahwa masing-masing variabel bebas mempunyai nilai koefisien positif dan negatif. Koefisien variabel yang bernilai positif memberikan arti bahwa waktu yang dibutuhkan untuk mendapatkan anak pertama relatif lebih pendek (lebih cepat mendapatkan anak pertama). Begitu juga sebaliknya, koefisien variabel yang bernilai negatif mengindikasikan lamanya waktu yang dibutuhkan untuk mendapatkan anak pertama.

Variabel $\mathrm{X}_{1}$ (tempat tinggal) memiliki rasio hazard sebesar 1.131. Dengan kata lain, perempuan yang bertempat tinggal di desa memiliki risiko untuk mendapatkan anak pertama lebih cepat 1.131 kali dari perempuan yang bertempat tinggal di kota. Variabel $\mathrm{X}_{2}$ (tingkat pendidikan) memiliki rasio hazard sebesar 0.742 untuk variabel $X_{2(1)}$ (lulus SMP) dan 0.766 untuk variabel $X_{2(2)}$ (lulus SMA). Nilai rasio hazard tersebut memberikan arti bahwa perempuan dengan tingkat pendidikan lulus SMP mempunyai risiko untuk mendapatkan anak pertamanya lebih lambat 0.742 kali dari perempuan yang pendidikannya lulus SD. Demikian juga dengan perempuan dengan latar pendidikan lulus SMA atau di atasnya akan memiliki risiko mendapatkan anak pertama lebih lambat 0.766 kali dari perempuan yang pendidikannya lulus SD. Dengan kata lain, semakin tinggi tingkat pendidikan yang ditamatkan, maka waktu tunggu mendapatkan anak pertamanya semakin lama.

Variabel $\mathrm{X}_{4}$ (pengetahuan tentang kesehatan kehamilan) mempunyai nilai koefisien sebesar -0.095 dengan rasio hazard sebesar 0.909 , artinya perempuan yang mendapatkan pengetahuan tentang kesehatan kehamilan memiliki risiko untuk mendapatkan anak pertama lebih lambat 0,909 kali dari perempuan yang tidak mendapatkan pengetahuan tentang kesehatan kehamilan. Untuk variabel $\mathrm{X}_{5(1)}$ (usia 21-25 tahun) dan $\mathrm{X}_{5(2)}$ (usia > 25 tahun) masing-masing mempunyai nilai rasio hazard sebesar 0.003 dan 0.189, dengan kata lain dapat diartikan bahwa perempuan yang menikah pada usia 21-25 tahun memiliki risiko mendapatkan anak pertamanya lebih lambat 0.003 kali dari perempuan yang menikah di usia 15-20 tahun. Sedangkan perempuan yang menikah di usia > 25 tahun memiliki risiko untuk mendapatkan anak pertamanya lebih lambat 0.189 kali dari perempuan yang menikah di usia 15-20 tahun.

\section{KESIMPULAN}

Persamaan model regresi cox regresi proportional hazard yang dapat digunakan untuk memodelkan selang waktu mendapatkan anak pertama adalah sebagai berikut:

$$
\mathrm{h}(\mathrm{t})=\mathrm{h}_{0}(\mathrm{t}) \exp \left[0.123 \mathrm{X}_{1}-0.299 \mathrm{X}_{2(1)}-0.267 \mathrm{X}_{2(2)}-0.095 \mathrm{X}_{4}-5.823 \mathrm{X}_{5(1)}-1.665 \mathrm{X}_{5(2)}\right]
$$

Variabel $\mathrm{X}_{1}$ (tempat tinggal), $\mathrm{X}_{2}$ (tingkat pendidikan), $\mathrm{X}_{4}$ (pengetahuan tentang kesehatan kehamilan) dan $\mathrm{X}_{5}$ (usia pada saat menikah) merupakan variabel bebas yang memberikan pengaruh nyata terhadap waktu tunggu mendapatkan anak pertama pada nyata $\alpha=5 \%$.

\section{DAFTAR PUSTAKA}

Al Farisyi, M., \& Khambri, D. (2018). Analisis Survival Pasien Kanker Payudara Usia Muda di RSUP DR. M. Djamil Padang Tahun 2008-2017. Jurnal Kesehatan Andalas, 7(Supplement 4), 25. https://doi.org/10.25077/jka.v7i0.917

Badan Pusat Statistik. (2015). Proyeksi Penduduk Indonesia 2015 - 2045 Hasil SUPAS 2015. https://www.bps.go.id/indicator/12/1886/1/jumlah-penduduk-hasil-proyeksi-menurut-provinsi-danjenis-kelamin.html

Faruk, A., Amran, A., \& Nasir, N. (2014). Aplikasi Model Proportional Hazard Cox pada Waktu Tunggu Kerja Lulusan Jurusan Matematika Fakultas MIPA Universitas Sriwijaya. Jurnal Penelitian Sains, $17(1), 17102-17105$. 
https://jurnal.unsulbar.ac.id/index.php/saintifik

Hudori, M. (2016). Analisis Daya Tahan Menunggu Kelahiran Anak Pertama di Provinsi Lampung [IPB University]. https://repository.ipb.ac.id/jspui/bitstream/123456789/80508/1/2016mhu.pdf

Kleinbaum, D. G. D., \& Klein, M. (2011). Survival Analysis: A Self-Learning Text, Third Edition (Statistics for Biology and Health). In Biometrical Journal. https://doi.org/10.1016/B978-0-12-387667-6.00013-0

Marisa, Yozza, H., \& Maiyastri. (2017). Model Regresi Cox Proportional Hazard Pada Laju Tamat Mahasiswa Jurusan . Matematika Universitas Andalas. Jurnal Matematika UNAND, 6(1), 33. https://doi.org/10.25077/jmu.6.1.33-41.2017

Setiani, E., Sudarno, S., \& Santoso, R. (2019). Perbandingan Model Regresi Cox Proportional Hazard Menggunakan Metode Breslow dan Efron (Studi Kasus: Penderita Stroke di RSUD Tugurejo Kota Semarang). Jurnal Gaussian, 8(1), 93-105. https://doi.org/10.14710/j.gauss.v8i1.26624 